under the body. The lower articular extremity of the left humerus, together with part of the shaft, to the extent of about an inch, protruded through a transverse wound at the lower and anterior part of the arm. The external condyle of the humerus was broken in one or two portions. The lower lip of the wound was stretched beneath the protruded bone, over the anterior surface of which the median nerve ran across in a state of great tension, but without any apparent laceration. The hand was cold, and no pulsation was sensible in either the ulnar or radial artery. Little or no hæmorrhage, considerable effusion of blood, however, above the protruded bone; radius and ulna thrown backwards, not, however, broken; no sensation in the middle finger.

The forearm having been drawn backwards, and the median nerve slipped over the inner side of the dislocated humerns; the articular extremity, together with about an inch of the shaft, was removed with the saw. Several loose portions of bone, also, having been taken away, the forearm was brought together at right angles to the arm, the wound dressed with wet lint, and the extremity placed loosely in an angular splint. One hour after the operation, the pulse was 90 , and irregular, the hand still cold. He went into a quiet sleep at eight in the evening, and continued so during the night without the aid of opium. On the following morning the forearm was warm, and there was no pain at the elbow; considerable pain, however, came on about one in the afternoon, the skin being tense and hot; very little general excitement, the pulse being rather quicker and sharper, but having lost its irregularity. The bandage was slit up and cold lotion kept constantly applied, and he was ordered saline medicine every four hours.

March 26th.-Pulse 120, and sharp; tongue white; bowels confined. Calomel and rhubarb, ten grains. On the following morning the pulse had fallen and the fever had diminished; the pain in the arm rather greater. Six leeches to the elbow.

30th.-A degree of general irritability had now supervened; the pulse was 95 , small and feeble; he had passed a restless night; slight purulent thin discharge from the wound. Ordered, beef-tea, and decoction of cinchona, one ounce three times a day.

31st.-Considerable anxiety in his expression; passed, however, a better night. He screamed, however, at intervals; pulse 108. On the 2nd of April, the pulsation in the radial artery was just sensible, and became distinct on the 4 th.

From this period he went on favourably till the 24th, when an attack of acute inflammation came on in the elbow, leading to the formation of an abscess. After this had been opened, he improved rapidly. The wound where the bone protruded had healed about the beginning of May, all swelling having subsided, and the numbness which had previously existed in the hand, but affecting principally the middle finger, had ceased; the forearm was midway between pronation and supination, and there existed slight power of flexion and extension at the elbow-joint; this, however, could not be brought about except the forearm was supported with the opposite hand. Passive movement of the elbow was now commenced. He left his bed about the 10th of May, but was so feeble that he walked with a tottering gait, his features being pale and wan. He gradually recovered strength, and on July 4th, was sent into the country for change of air ; the extremity being in the same condition as above mentioned, with the exception that he could extend and flex the forearm without the aid of the other hand. He had perfect command over his fingers, but no power of pronating or supinating the hand.

Remarks.-On considering the complicated nature of the injuries in the present instance, it is a matter of surprise that the case should have terminated favourably without the removal of the limb. The great tension of the median nerve, the injury to the chief vessels of the forearm, the laceration of the soft parts, and the fractured condition of part of the protruded bone, seemed to point to immediate amputation. Opinion, in fact, was divided, as to the propriety of the treatment adopted, the various lesions appearing to counterbalance the reparative powers, which are exhibited to so great an extent during youth, and which numerous cases on record so amply demonstrate.

It may be asked-Why was the lower extremity of the bone sawed off instead of being reduced? It was almost denuded from connexion with the soft parts, the lower part broken near the outer condyle, and the periosteum injured. The removal, therefore, of the bone, saved, in all probability, a tedious process of necrosis; and a source of great constitutional irritation, consequently, was done away with, and the cure much more rapidly effected than would have otherwise been the case

\section{A LETTER FROM W. O'CONNOR, ESQ.} To the Editor of THE LANCET.

SIR,-Since Friday last, my attention has frequently been called to a paragraph in The LANCET of that day, (page 223,) in which you state, in answer to a correspondent, that I have "concurred. in the publication of a history in which accuracy and truth are not prominent characteristics." I should not have noticed the paragraph in question in a public manner, but having been told that the allusion to myself was made in a way calculated to give many an undue impression, I am prompted to intrude upon your columns.

Thongh a member of the Committee, I did not vote for oragainst any paragraph in the Address. I have ceased to take any part in the proceedings of the Committee. Why I have done so, shall presently show.

To prevent intrusion at any future time on the notice of yourreaders, I embrace the opportunity this communication affords, for the purpose of giving a history of the proceedings of the Marylebone Association, which probably may prove interesting to some members of the profession, after briefly noticing the sixth paragraph of the Address. The words of which are as follow"The general practitioners stood forward en masse to prevent legislation on such a principle, the attempt at which they considered a grievous public wrong. Thus originated the National Association."-It is hardly necessary for me to attempt todisprove this paragraph. Reference to the medical journals for four months after the introduction of the Bill, and the formation of the Mary. lebone Association, will prove that the general practitioners were slow in their movements, and that they followed the example of the Marylebone practitioners, though at many of the meetings in the country, resolutions approving of the Bill were adopted.

That the Marylebone Association was the first of exclusively general practitioners since the year 1815 , is a fact. Tha was the originator of that Association, will not, I presume, be denied. The following extract from a medical journal of the 24 th of August, 1844, supports these assertions:- " the honorary secretary, Mr. O'Connor, of George-street, to whose able exertions the profession is mainly indebted for this first medical demonstration, was called on to read the minutes of the preliminary meeting."

On the 8th of August, 1844, I read in the Times newspaper the report of a speech delivered by Sir James Graham in the House of Commons, on his introduction of a Bill for the regulation of the profession. I felt somewhat alarmed for the future position of the general practitioners, and my alarm was increased on perusing the leading article in THE LANCET of the 9th of the same month. It then occurred to me that the time had arrived for reducing to practice a plan for organization which might really benefit the general practitioners, for I frequently had noticed the British Association and other associations, established with the view of effecting reform in the profession, were all but powerless, attributable in a great measure to the association of General Practitioners with other classes of the profession-physicians who secretly performed the duties they at other times. declared beneath their dignity - with pretended " pures," both of" whom look with envy on the position general practitioners occupy in the estimation of the public.

$I$ invited about thirty-five general practitioners of the borough to meet at the Literary Institution, Edward-street, Portmansquare, on Monday evening, the 12th of August, when I brought under their notice the speech of Sir James Graham, and stated my propositions-

"1st. That an Association of General Practitioners should be formed in each parliamentary boundary.

" 2 nd. That an executive board should be formed in London, by representation from each of the Associations so formed, the duties of which should be not only to endeavour to defeat any bad measures, but to frame strch a Bill as would be suitable to the wants of the profession throughout the empire."

The result was, that a public meeting of the general practitioners of the borough was held on the $17 \mathrm{th}$, a notice of which will be found in The Lancet of the 24th.

That my plan was entertained and adopted is proved by the existence of the Marylebone Association, as well as the following resolution, carried at the first public mecting:-

" Proposed by W. R. Vickers, Esq., seconded by H. Hodding, Esq., That this meeting expresses its earnest hope that meetings of medical practitioners will be held in all the metropolitan districts, and committees formed, with the same objects as those of the borough of Marylebone Medical and Surgical Association, and that the various committees will confer together, for the purpose of securing unity of action in carrying out their objects."

And also, by the following extract :- 
"That it has been further suggested, for the purpose of ensuring unanimity on these important topics, that each local Society throughout the kingdom should select one or more delegates, to meet three months hence in London, with power to agree upon one general plan of operations, both in opposing the Bill, and at the same time in bringing forward a liberal and comprehensive plan for the government of the general practitioner; and that the committee of the Medical and Surgical Association of the Borough of Marylebone is of opinion this suggestion deserves attention."-(Marylebone Manifesto, paragraph 36.)

Shortly after the general meeting, resolutions, adopted by the Court of Assistants of the Society of Apothecaries, appeared in the Times, and forthwith I summoned a meeting of the committee, 6" to consider the resolutions of the Court of Assistants of the Society of Apathecaries in connexion with Sir James Graham's Bill," when I suggested a conference with that body, which I was directed to apply for. In consequence of the absence of Mr. Upton from town, some delay occurred before $I$ received the following:-

“ Apothecaries' Hall, September 24th, 1844.

"Sir, - I am directed by the Master and Wardens to inform you, that the Society of Apothecaries will be happy to receive a deputation from the Committee of the Medical and Surgical Association of the borough of Marylebone, on Tuesday, the 1st October, at half-past two o'clock, and the Miaster and Wardens hope that day and hour will be convenient to the deputation.

"I am, sir, your very obedient servant,

"Roвert B. Upton, Clerk to the Society.

"W. O'Connor, Esq., \&c."

The deputation (consisting of the following gentlemen:Messrs. Squibb, Clayton, Propert, Craddock, Vickers, Brown, Bird, Ancell, and myself) was appointed, and a meeting was held at my residence, when the following, drawn up by Mr. Ancell, was agreed on, and given to Mr. Squibb, as chairman:-

"Memorandum for Conference with the Worshipful Company of A pothecaries. 1st October, 1844. G. J. SQursB, Esq., chairman of the sub-committee.

“1. In compliance with the Company's invitation to the profession, the committee has deemed it expedient to propose a conference.

“2. The committee is anxious to know whether, in the opinion of the Company, the Medical Bill should be opposed in toto.

"3. The committee is anxious to learn the opinion of the Company respecting the present aspect of medical affairs, and more particularly as to the course which it would be most expedient for the licentiates of the Company and general practitioners to pursue.

"4. To learn whether the Company be prepared to propose any alterations in the Act of 1815

“ 5. It will more especially further the future proceedings of the committee, supposing the Company and the various local committees now in existence should ultimately agree to co-operate in forming one collective body of general practitioners, if the Comnany would state its opinion as to the most practicable way of doing so.

"Would it be more expedient that the rarious committees should at once set on foot a more perfect organization of the general practitioners, and that the new society petition for a Charter for a College of Medicine and Surgery, receiving the support and cordial co-operation of the Company, and its consent to repeal the existing Apothecaries' Act? Or,

"Would it be more expedient that the Company, with the cordial support of the various committees, should take the initiativepetitioning Parliament for a modification of the existing Act, with increased powers to examine future candidates as general practitioners of medicine and surgery? Or, lastly,

"Is the Company prepared to suggest a plan, to secure the success of which it would desire to have the co-operation of the Committee?"

On the day appointed, the deputation, with the exception, I believe, of Messrs. Propert, Clayton, and Craddock, attended at the Hall, and was graciously received by the Court of Assistants, to whom, after some interesting conversation on the Bill, the "Memorandum" was read by Mr. Squibb. The Court desired a copy, and a week to consider its contents, at the expiration of which time I received the following letter, as secretary :-

“'Apothecaries' Hall, sth October, 1844.

"SrR, - I am directed by the master and wardens of this Society to inform you that the Committee of the Society have had under their consideration the questions proposed to them by the deputation from the Committee of the Medical and Surgical Association of the borough of Marylebone, at the interview with which the deputation honoured them on Tuesday last.

"The Committee find, upon a careful examination of these questions, that they involve little less than the whole subject of medical reform.

"The Society are not, as yet, in possession of the communications which they have invifed from other medical associations, on the subject of the Bill recently introduced by Sir James Graham, and which they are still in the hope of receiving. Meanwhile, the Committee are themselves proceeding with a careful investigation of the provisions of the measure, with the intention of laying before the profession the impression which has been produced on their minds by a more mature consideration of its details, and of communicating their opinion in reference to the mode in which the Society can best further the views and wishes of their professional brethren. Under these circumstances, the Committee do not find themselves, at present, in a situation to reply to the specific questions proposed to them by your body.

"The Committee of the Medical and Surgical Association of the borough of Marylebone, however, may rest assured that the Society of A pothecaries are prepared to meet the subject upon broad and liberal principles, apart from all municipal, corporate, or personal considerations, and with a single view to the interests of the profession and the public.

"I am, Sir, your most obedient servant, "RoвT. B. Upton, Clerk to the Society.

"Wm. O'Connor, Esq., \&c."

Shortly after, "The Marylebone Manifesto" appeared. During this time, conferences with the Colleges of Physicians and Surgenns were contemplated; the proposal, for a time, was objected to, but in the beginning of November the Committee directed a copy of "The Manifesto" to be forwarded to the Colleges, and requesting a conference.

On the 9th of November, the application to the College of Surgeons was acknowledged by Mr. Belfour, who stated he "would lay the same before the Council at its next meeting." In answer to the application to "The President of the Royal College of Physicians, Pall Mall," I received the following, dated fiom Dover-street, but written at the Athencum Club :-

" Dover-street, November 15th, 1844.

"SIR,-I heg you will convey my thanks to the president and committee of the Medical and Surgical Association of Marylebone, for the "Manifesto" you were so good as to forward to me.

"As a committee of the College of Physicians is at present engaged in considering the provisions of the Medical Bill, I must decline any conference, on my part, as a premature step.

"I remain your obedient servant,

“W. O'Connor, Esq., \&c."

"J. A. Paris.

It is worth observing, that although a Committee of the College of Physicians was at the time "engaged in considering the provisions of the Medical Bill," the President did not consult the members of that committee before replying to the request of the association.

On the 22nd of November, I received the following:"Royal College of Surgeons of England, November $22 n d, 1844$.

"SIR,-I am directed, in reply to your communication to the Council of this College, to acquaint you that the president and vice-presidents will be happy to receive (at this College) any three members of the committee of the Medical and Surgical Association of the borough of Marylebone, being members of the College.

"I am also directed to mention that five o'clock on Friday next, the 29 th inst., would be convenient to the president and vice-presidents of this College, should that hour be convenient to those gentlemen who may be deputed to meet them.

"I have the honour to be, Sir, your obedient servant,

"W. O'Connor, Esq., \&c."

"EDM. Belfodr, Sec.

In consequence of the number being limited, Messrs. Propert, Clayton, and Squibb were appointed on the part of the committee, to whom the following questions, drawn up by Mr. Bird, and agreed to by a sub-committee, were entrusted.

1st. Is the Council of the College prepared to oppose the reintroduction of Sir James Graham's Bill?

2nd. Is the Council of the College prepared to aid or oppose their members, who are also licentiates of the Apothecaries Hall, in their application for a charter of incorporation for "A College of General Practitioners in Medicine, Surgery, and Midwifery"?

3rd. Is the Council of the College prepared to make any modification in the Charter lately granted to the-Conncil?

Previously to the day appointed for the conference, a private meeting was held at the house of the respected president, attended by Messrs. Propert, Squibb, Dodd, Vickers, Tupper, Fuller, Nussey, Ridout, Bacot, Freeman, Tegart, Bird, and An- 
cell, the result of which was the adoption of the requisition published in the medical journals of the 30th Nor. Subsequent to this date, (the 30th Nov.,) a committee meeting was held to receive the report from the deputation appointed to confer with the president and vice-presidents of the College of Surgeons, which was to the effect that, "With the two first questions, the president and vice-presidents had nothing to say, but asked what modification the deputation suggested should be made in the Charter lately granted to the College?" The committee, after consideration, passed a resolation, drawn up by Mr. Ancell, declining to suggest any modification, and also expressive of its disapprobation of the manner in which the Charter was framed and its provisions carried out.

On the 7th of December, the first meeting was held at the Hanover-square Rooms, and "Thus," it is said, "originated the National Association."

I will now explain the cause of my discontinuing to attend the meetings of the committee.

After the Bill of the $7 \mathrm{th}$ of May, (the third Bill of the minister, ) my astonishment was great on finding that the position of the general practitioners in Ireland and Scotland, with respect to collegiate incorporation, differed widely from that of the general practitioners in this country, and the examinations in those countries were not to be conducted in the same manner; they were to be arranged so as to prove highly injurious to the general practitioners of England, as will be seen by referring to, and viewing in connexion, clauses 14,17 , and 20 , of that, the since abandoned, Bill; and, moreover, the Bill converted the Colleges of Surgeons of Ireland and Scotland into Colleges of General Practitioners, whilst by recognising a College of General Practitioners in England, it converted the College of Surgeons of England into a College of "pures." I was the first to draw attention to these clauses: they were briefly noticed, some time after, by Professor 'Todd, of King's College, in the Morning Herald. I wished, by correcting them, to establish equality of examination, and collegiate incorporation for the respective classes in the different parts of the empire, and thus carry out more effectually the principle of the Bill-universality of practice, and universality of qualification. So strongly did $\mathrm{Mr}$. Hawes, M.P., feel the force of my objection, that he desired to have it on paper, and in a letter in reply, of June 1st, stated-“ I am quite alive to your objection; it is important, most important, and I will not neglect it.

About the 4th or 5 th of June, a deputation, consisting of Dr. Atkinson, of Dublin, (one of the examiners of the Apothecaries Hall of Ireland,) and Mr. Gordon, of Cork, fully authorized by the general practitioners of Ireland to negotiate for them in London, called on me to be made acquainted with the views of the committee of the National Association. I brought the deputation, as they desired, in direct communication with the secretaries, Messrs. Ancell and Bird, to whom they stated the object of their mission, and further suggested to them the propriety of seeking for a College of General Practitioners in Ireland and Scotland, as well as in England, the three acting in unison, to be governed by similar laws; or, one College for the United Kingdom, each country to be represented in the Council according to the number of general practitioners. About the same time, a somewhat similar proposition was made to the committee through Dr. Webster, by the Glasgow Medical Association. Dr. Atkieson and Mr. Gordon stated, that unless either of their propositions was agreed to by the minister, they had a parliamentary force at their command, which they would bring to oppose the Bill in toto, but that they were willing to co-operate with the Association upon the conditions at first stated.

We left the office with a distinct understanding that the secretaries would report to the committee the conversation which had taken place, as the following correspondence will show.

$$
\text { " George-street, Portman-square, London. }
$$
"August 23rd, 1845 .

"MY Dear Srr, -I will feel obliged by your informing me, by return of post, whether you understood that the conversation which took place on the subjects of the Medical Bill of Sir James Graham and the proposed College of General Practitioners, with Messrs. Ancell and Bird, on the day that I accompanied yourself and Dr. Atkinson to the office of the National Association, was to be reported to the committee, and whether you did or not expect a communication from that body in reply.

"Believe me, my dear Sir, very faithfully yours,

"J. Gordon, Esq."

"WM. O'CONNOR.

Cork, 31, Patrick-street, August 25th, 1845

“ My Dear Sir, - I can have no hesitation whatever in answering your queries.

"The conversation which I and my colleague, Dr. Atkinson had with Messrs. Ancell and Bird in your presence, relative to
Sir James Graham's Bill and the proposed College of General Practitioners, at the office of the National Association, in June last, had for its object, the conveying to the committee which those gentlemen represented, the views of the apothecaries and general practitioners of this country, and I certainly (and I am sure Dr. Atkinson participated in that feeling) was greatly disappointed, nay, somewhat offended, at no official notice, in way of reply, from the committee having been vouchsafed to us.

"Believe me, my dear Sir, yours faithfully,

"w. O'Connor, Esq."

"JoHn Gordon.

Dr. Atkinson's reply is to the same effect as that of $\mathbf{M r}$. Gordon.

Those gentlemen, after the interview with the secretaries, waited for a fortnight, and, as will be seen by the above, no reply was given.

On the 17 th of June, Dr. Atkinson and Mr. Gordon procured a meeting of members of parliament, to the amount of twenty, at an hotel in Palace-yard, when amendments to the Bill were agreed on, and entrusted to Serjeant Murphy. Actuated by an independent spirit, rather than cringe to a vacillating minister, they declared their opposition to the Bill, and were prepared with an opposition in the house, including individuals of all shades of politics, among whom were-Messrs. Shaw, Shiel, Murphy, Wyse, Hamilton, Smith O'Brien, D. O'Connell, J. O'Connell, M. J. O'Connell, Grogan, Gregory, Roche, O'Connor Don, Serjeant Murphy, and other members of parliament. This opposition, of which the minister was aware, contributed as much (if not more) towards the defeat of the Bill as the efforts of the Colleges of Physicians and Surgeons.

About the same time that the meeting was being held at Palaceyard, I asked the Chairman of the Committee of the National Association, then sitting, if he ever heard of the conference with Dr. Atkinson and Mr. Gordon, and he replied that he had not; but Mr. Bird said, in reply, that some gentlemen who had waited on him and Mr. Ancell were desirous of obtaining an offshoot of the new College; an assertior which, to say the least of it, was " simply untrue." Being convinced that " self-interest must be continually opposed to the public good," (Marylebone Manifesto, p. 13, I have ceased from that day to attend the meetings of the Committee.

Having given this history, in which "accuracy and truth" will be found "prominent characteristics," I trust it will be the means of preventing my name being made the subject of editorial comment.

From the first, my object was, as a young and humble member of the profession, to effect such an organization of general practitioners as would have sufficient power at command to remedy the evils under which they labour.

Perhaps I have incurred some censure for bringing before the public, men, who, quietly pursuing their professional duties, had never before mixed in "agitation." If such be really the case, my apology is, that the agitation prevented bad measures from being passed; and I have to express my regret, in common, I am sure, with many others, that matters have not been brought to a more favourable termination. I remain, Sir, your obedient servant, WIIIIAM O'CONNOR.

21, George-street, Portman-square, August 2\%th, 1845.

\section{DR. STEW ARD'S NOTES ON INSANITY. To the Editor of The LaNcET.}

SrR,-All who require their services, most undoubtedly owe muck to those who take upon themselves the duty of reviewers; and $\mathbf{I}$ should as soon think of asking a man's opinion, and then quarrelling with him because it was not to my taste, so complain of the severity of that public ordeal.

But when, as I hope to show is my case, the author's meaning has been misunderstood, not only is he justified, but, I submit, even bound, to defend himself; and you, Sir, I am sure, are too just not to afford him the opportunity of doing so.

It is with such a feeling I request you to insert this letter; and that I may not unnecessarily occupy your valuable columns, $I$ will reply as briefly as possible, and in the order in which they occur, to the charges brought against me by your reviewer.

First, the reviewer observes- "But what principles have we found in the volume, with which the author desires our concurrence? At page 2, he observes, "That the course he has marked out for himself, not requiring the usual divisions of insanity, the reader will, throughout the following pages, find the terms ' insanity' and 'mania' used synonymously.' Thus all the recognised forms of insanity are jumbled together under the synonymes 'insanity' and 'mania'- a commingling of cerebral diseases, which is very unlikely to yield scientific results." 